\title{
LOCALE-VARYING RELATIONSHIPS BETWEEN TOURISM DEVELOPMENT AND RETAIL PROPERTY PRICES IN A SHOPPING DESTINATION
}

\author{
Linchuan YANG (D) ${ }^{1}$, K. W. CHAU (D) ${ }^{2}$, Yi LU (D) ${ }^{3}, \mathrm{Xu} \mathrm{CUI}^{1}$, Fanyu MENG ${ }^{4}, \mathrm{Xu} \mathrm{WANG}^{5}{ }^{*}$ \\ ${ }^{1}$ Department of Urban and Rural Planning, Southwest Jiaotong University, Chengdu, Sichuan, China \\ 2 Department of Real Estate and Construction, The University of Hong Kong, Hong Kong, China \\ ${ }^{3}$ Department of Architecture and Civil Engineering, City University of Hong Kong, Hong Kong, China \\ ${ }^{4}$ Academy for Advanced Interdisciplinary Studies, Southern University of Science and Technology, \\ Shenzhen, China \\ ${ }^{5}$ Department of Natural Resources of Sichuan Province, Chengdu, China
}

Received 24 September 2019; accepted 22 January 2020

\begin{abstract}
Existing literature has inadequately examined the nexus between tourism and property prices. Additionally, it mainly focuses on hotels and housing, thereby overlooking other property categories (e.g., retail properties). The relationship between tourism development and retail property prices in shopping destinations (e.g., Hong Kong and Singapore) may hinge on the locale. More specifically, the relationship may be different in the tourist precinct or popular tourism shopping area (PTSA) and the unpopular tourism shopping area (UTSA). This study examines locale-varying relationships between tourism development (measured by tourist volume and tourism expenditure) and retail property prices from 2002Q1 to 2014Q4 in Hong Kong using standard and error-correction-model-based (ECM-based) Granger causality tests. Results of standard Granger causality tests indicate that tourism development Granger causes the increase in retail property prices in the PTSA but not in the UTSA. Moreover, results of ECM-based Granger causality tests further verify the robustness and plausibility of the tourism-led growth (in retail property prices) hypothesis in the PTSA. In other words, we find that tourism development measures can be used to better predict changes in retail property prices in the PTSA than simply referring to the price history.
\end{abstract}

Keywords: tourism development, retail property price, tourism shopping, tourist shopper, Granger causality test, Hong Kong.

\section{Introduction}

Tourism is an integral part of the ongoing globalization. Its demand has tremendously increased recently: International tourist volume in 2017 experienced a 7.0\% increase, compared with 2016 (UNWTO, 2018); and tourism receipts growth from 2016 to 2017 was $4.9 \%$ (UNWTO, 2018), whereas world GDP growth during the period was just 3.3\% (UNWTO, 2018) ${ }^{1}$. It is widely acknowledged that tourism development (or tourism expansion) is driven by numerous factors, such as economic upswings, long holiday, and an increase in the number of retirees with disposable time and income (Biagi et al., 2015).

\footnotetext{
1 Source: https://data.worldbank.org/indicator/NY.GDP.MKTP. KD.ZG
}

Tourism development influences multiple aspects of a tourist destination (e.g., city, region, and country), such as economic growth (or economic development), balance of payments, provision and utilization of tourism facilities (e.g., restaurants and accommodations), employment creation, income equality, and social capital. Numerous researchers worldwide have long recognized the significant impact of tourism development on economic growth (Kim \& Chen, 2006; Arslanturk et al., 2011). Note that economic growth is often assessed by gross domestic product (GDP) in their studies, mainly because GDP is the most tangible and compelling available measure. Generally, the positive relationship between tourism development and economic growth or the contributions of tourism development to a country's/city's economy has been confirmed in numerous previous studies (e.g., Oh, 2005;

${ }^{*}$ Corresponding author. E-mail: 248566136@qq.com 
Roudi et al., 2019; T. P. Wu \& H. C. Wu, 2019). This result is consistent with intuition and industry wisdom.

Since an increase in property prices can be a result of economic growth, it is reasonable to suspect that tourism demand could impact property prices. As such, the linkages between tourism demand and property prices are worthy of rigorous investigation because a better and more thorough understanding of such linkages can inform tourism/real estate policy-makers and practitioners (e.g., real estate investors/developers/portfolio managers and tourist destination marketers/planners), retailers, and tourists to make more informed strategic decisions. The majority of previous studies on tourism and property prices focus on two property types, namely hotels and housing (or residential properties) (Fereidouni, 2013). The impact of tourism on the former is more direct while that on the latter is much more complicated. These studies usually find positive linkages between tourism and property prices, although their findings are still inconclusive. However, retail properties have been largely overlooked (Liu et al., 2020). As of today, no empirical research focuses on the effect of tourism development on retail property price trends in varying locales of a shopping destination.

Shopping is among the oldest, most important, universal tourism activities (Turner \& Reisinger, 2001; Choi et al., 2016; Pantano \& Dennis, 2019), especially in shopping destinations (e.g., Hong Kong) (Law \& Au, 2000; Turner \& Reisinger, 2001; Zaidan, 2016). It is an essential reason behind travel (Meng \& Xu, 2012) and a determinant of tourists' choice of destinations (Choi et al., 2016). Tourism shopping becomes increasingly crucial in today's era of materialism and consumption (Murphy et al., 2011; Zaidan, 2016). To date, numerous studies have devoted themselves to unraveling many topics in tourism shopping: its nature (Meng \& Xu, 2012), its importance (Murphy et al., 2011; Choi et al., 2016; Pantano \& Dennis, 2019), its contribution to a tourist destination's economy (Law \& Au, 2000), its role in shaping tourist destination choices (Moscardo, 2004; Zaidan, 2016), the motivation, satisfaction, and/or behaviors of tourist shoppers (Turner \& Reisinger, 2001; Kemperman et al., 2009; Meng \& Xu, 2012; Kattiyapornpong \& Miller, 2012; Liu, 2014), etc. However, the association between tourism development and prices of retail properties (where tourism shopping activities mostly happen) in a shopping destination has long been overlooked in existing literature.

Hong Kong is a well-known international tourist destination. Despite its small size, Hong Kong's tourist volume (visitor arrivals) and tourism receipts constituted $8.6 \%$ and $8.5 \%$ of those of Asia and the Pacific region, respectively, in 2018. These two figures were close to those of Japan $(8.9 \%$ and $8.7 \%)$ and more than twice those of South Korea (4.1\% and 3.4\%) (UNWTO, 2018). Furthermore, Hong Kong has a famous global reputation as a "shopping paradise" and is a representative shopping destination (Law \& Au, 2000).
In this study, based on retail property transaction data from 2002Q1 to 2014Q4 (a 13-year horizon), quarterly repeat-sales retail property price indices in the tourist precinct or popular tourism shopping area (PTSA) and the unpopular tourism shopping areas (UTSA) of Hong Kong are constructed. In line with Kim and Chen (2006) and Song et al. (2010), two indicators, namely tourist volume (or visitor arrivals) and tourism expenditure (or total tourism receipts associated with inbound tourism $)^{2}$, are used to measure tourism development. Standard and errorcorrection-model-based (ECM-based) Granger causality tests (Granger, 1969; Engle \& Granger, 1987) are used to examine the relationships between tourism development and retail property prices in the two areas separately. The results indicate that tourism development Granger causes retail property price increases in the PTSA but not in the UTSA. The results are robust across different tests and tourism development measures, which further strengthens the plausibility of this study. The contributions of this study include: 1) analyzing the role of tourism development in determining the retail property price trends of a shopping destination; 2) comparing the differences in the role in different locales of a shopping destination; and 3) discussing practical implications for the PTSA and the UTSA.

The remainder of the paper is organized as follows. Section 1 reviews existing studies on tourism and property prices. Section 2 develops several hypotheses. Section 3 reveals the study area and data. Section 4 presents the repeat-sales property price index construction method, the index frequency-conversion estimation technique (Generalized Inverse Estimator), and standard and ECM-based Granger causality tests. Section 5 summarizes the empirical results. The last section concludes the paper, discusses practical implications, and puts forth avenues for future research.

\section{Literature review: tourism and property prices}

The effect of tourism on the property market is understudied ( $\mathrm{Gu}$ et al., 2017). Relevant studies have mostly been from the fields of tourism economics and real estate economics. Most of them have explored the association between specific (tourism) amenities and nearby property prices, and others have analyzed the comprehensive effect of tourism on property prices.

Numerous studies have applied hedonic pricing models to tease out the effect of tourism amenities (or tourism-related attributes) on nearby property prices. These studies suggest that proximity to amenities and pleasant landscape/view have significant positive correlations with property prices. Most, although not all, studies have adopted individual-level (or property-level) hedonic

\footnotetext{
2 Unlike quarterly tourism volume data, tourism expenditure data are only published on an annual basis. As such, the linear interpolation frequency-conversion method was used to obtain quarterly tourism expenditure data.
} 
pricing models and have empirically demonstrated that property purchasers or renters are willing to pay for proximity to amenities and pleasant landscape/view.

The impact of proximity to the city/town center on travel accommodation prices has attracted substantial scholarly attention. Schamel (2012) found a positive association between proximity to the city center and hotel room rates in Bolzano, Italy. White and Mulligan (2002) reported that hotels located in metropolitan locations exhibit higher prices than those outside the areas. Wang and Nicolau (2017) concluded that distance to the city center is negatively associated with accommodations' listed prices. However, Chen and Rothschild (2010) reached an opposite conclusion: proximity to the city center negatively affects hotel room rates in Taipei. They suggested that a possible explanation for their counter-intuitive finding is that hotels outside the city often offer a variety of premium amenities (e.g., hot springs). Lee and Jang (2012) comprehensively analyzed the relationship between Chicago's central downtown location and hotel room rates and observed a dual effect of the central downtown location. Moreover, they found that the price effect of the central downtown location strongly hinges on the season.

The effect of proximity to focal points, such as scenic points, coasts, beaches, golf courses, and heritage conservation sites, has been empirically assessed. Espinet et al. (2003) observed that distance to the beach is negatively related to hotel prices in three tourist resorts in Spain. Nicholls and Crompton (2007) determined that property prices are significantly affected by golf courses in Texas, the United States. Zhang et al. (2011) reported that the effect of distance to scenic points on hotel prices varies across different locations in Beijing, which justifies the use of geographically weighted regression. Schäfer and Hirsch (2017) used traditional hedonic pricing models and generalized additive models to examine the contributory role of urban tourism hotspots in determining housing rentals in Berlin, Germany. Their results confirmed that housing rentals are positively correlated with a location's touristic attractiveness. To sum up, these findings are relatively consistent: proximity to focal points is positively related to higher property rentals/prices. However, focal points do not always positively affect nearby property prices. For example, White and Mulligan (2002) suggested that interstate locations are negatively correlated with nearby hotel prices because of noise and hyper-competition with neighboring hotels.

The contributory role of view (e.g., sea view, water view, landscape view, garden view, and road view) from the property has also been investigated. Chau et al. (2003) indicated that properties with a sea view are more expensive than those without such a view, ceteris paribus, in Hong Kong. Chau et al. (2004) confirmed that a landscape view and a road view are significant contributory factors in explaining housing prices in Mei Foo Sun Chuen, Hong Kong. Hui et al. (2012) showed that in Hong Kong, a sea view offers price premiums to low- and medium-floor properties but provides discounts to high-floor properties. This finding stood in contrast with common beliefs, and the explanation provided by the authors was weather conditions.

The impacts of big events (e.g., the Olympic Games) on changes in property prices have been examined in several empirical studies. Kontokosta (2012) estimated the Olympic Games' effects on house prices of host cities and found that the impacts vary vastly across cities. Kavetsos (2012) looked at the association between the Olympics announcement and property prices. They concluded that property prices in host exhibit are higher than those in non-host areas using difference-in-differences (DID) models. Likewise, Lu and Yang (2015) took a DID approach to assess the effect of the Sydney Olympics on property prices and observed different impacts in host and non-host suburbs.

Some studies have analyzed the overall (or holistic) effect of tourism (normally represented by a tourism index) on property prices. Using hedonic pricing models, Biagi and Faggian (2004) confirmed a positive relationship between tourism and housing prices in the Sardinian municipalities in Italy. Their intriguing study is among the first to establish a positive relationship between tourism and housing prices. Its conclusion was confirmed by Biagi et al. (2012). Biagi et al. (2015) took a system Generalized Method of Moments approach to examine the linkage between tourism and house prices in Italy and identified a positive linkage. However, they indicated that the linkage varies across cities. Biagi et al. (2016) emphasized that using a single model to relate housing prices to tourism and other variables cannot address individual heterogeneity. Thus, they used latent class models to estimate the effect of tourism activity on housing prices. Their findings suggested that the price effect of tourism is not universally positive: the positive impact mainly prevails in the centernorthern part, some well-recognized art cities, and a few small cities specializing in mountain tourism; and that the negative impact only exists in small cities specializing in marine tourism. Using a few autoregressive distributed lag models and Granger causality tests, Muzindutsi and Surujlal (2018) observed that in South Africa, tourism growth (measured by the increase in tourist accommodation expenditure) leads to property price growth in the long run.

By and large, previous studies have suggested that property renters/purchasers are inclined to pay extra for either specific tourism amenities or specific tourism-related activities. Most studies have used cross-sectional research designs, which can reflect the association between "specific" tourism amenities and property prices but cannot show before-and-after effects (Chau et al., 2003). Additionally, the majority of relevant studies single out one kind of tourism amenity in determining property prices, but their findings are case-specific or amenity-specific (Biagi et al., 2015). Thus, the findings cannot be generalized to a broader geographic context. Moreover, most but not all of the studies have focused on hotels and housing. 
Comparatively, other property categories (e.g., retail properties and offices) have been overlooked. Lastly, with regard to the methodology, hedonic pricing models have been used in most studies. However, these models suffer from a few problems that lead to biased and inconsistent estimates, including functional form misspecification, omitted variable bias, and disregard of spatial dependence (Yang et al., 2019a, 2019b, 2020a, 2020b).

\section{Development of hypotheses}

In shopping destinations (e.g., Hong Kong and Singapore), tourism development increases the number of tourists and associated tourism shopping activities and thus drives the demand for retail properties (where tourism shopping activities mostly happen). The increasing competition for retail properties is expected to enhance retail property prices as the property supply is often inelastic because of zoning and land-use restrictions. Therefore, a tourism-led growth in retail property prices is expected. However, the application of this hypothesis might hinge on the locale. More specifically, the hypothesis is expected to be valid in the PTSA (where tourists often go shopping). In contrast, in the UTSA (where tourist shoppers rarely visit and locals' day-to-day shopping activities happen), tourism development might not substantially introduce shopping activities. It might not trigger the demand for retail properties and affect their prices. Thus, the tourism-led growth hypothesis might not be correct in such locales, or tourism development might have little bearing on the retail property price growth in the UTSA. Therefore, the following two hypotheses are formulated:

Hypothesis 1: Tourism development Granger causes retail property prices in the PTSA.

Hypothesis 2: Tourism development does not Granger cause retail property prices in the UTSA.

To our knowledge, there have been no empirical studies devoted to confirming or refuting the two hypotheses. Therefore, this study makes the first attempt to examine the overall effect of tourism on retail property price dynamics, notably in different locales of a shopping destination, based on time-series data. Does tourism development cause retail property prices to change in the PTSA? Do retail property prices in the UTSA respond to tourism development? These two questions are what this study attempts to answer.

\section{Study area and data}

\subsection{Study area}

Hong Kong became a colony of the British Empire in 1842 , and its sovereignty was returned to China on July 1, 1997. At present, Hong Kong, commonly known as the "Pearl of the Orient", is one of China's two Special Administrative Regions, an international metropolis, and a core city in the Guangdong-Hong Kong-Macao Greater Bay Area. Located on the southern estuary of the Pearl River
Delta (and Guangdong Province), Hong Kong has a land area of $1,100 \mathrm{~km}^{2}$ or so and accommodates over 7 million residents.

Tourism is one of Hong Kong's four key industries, and it contributes approximately $5 \%$ of the city's GDP and provides jobs for about $7 \%$ of the population. Hong Kong is a popular shopping destination, especially for mainland Chinese tourists. The city's government has promoted the development of the tourism industry with a clear vision to establish the city as a premier tourist destination.

Figure 1 shows the city's quarterly tourist volume from 2002Q1 to 2014Q4. A steady, sharp increase in tourist volume can be observed. The yearly tourist volume grew from 17 million in 2002 to 61 million in 2014, representing cumulative growth of $259 \%$ over 12 years. Furthermore, $76.0 \%$ of the tourists were from mainland China, and the length of stay for overnight tourists was, on average, 3.1 days in 2018 (Hong Kong Tourism Board, 2018).

Figure 2 shows the city's yearly tourism receipts between 2002 and 2014. The increasing trend coincides with the increase in tourist volume. Data on tourist volume and tourism receipts are obtained from the Hong Kong Tourism Board (various issues).

Hong Kong is a representative shopping destination. According to the Hong Kong Tourism Board (2018), in 2018 , shopping accounted for $86.7 \%$ of same-day visitor

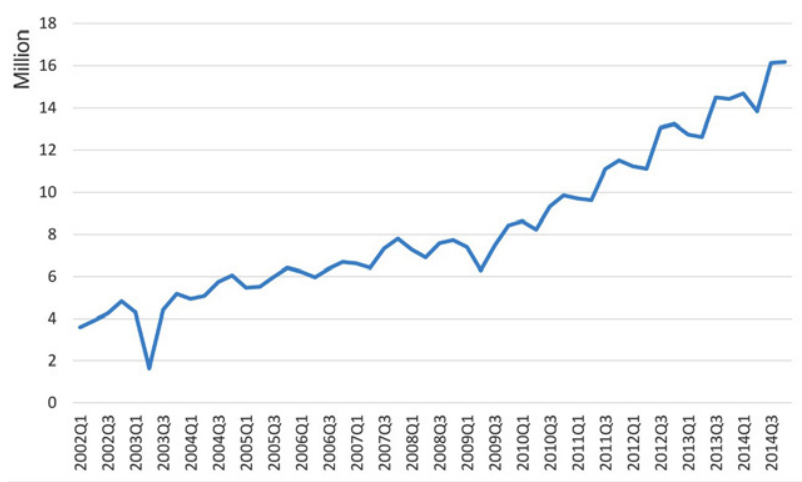

Figure 1. Quarterly Hong Kong tourist volume, 2002Q1-2014Q4

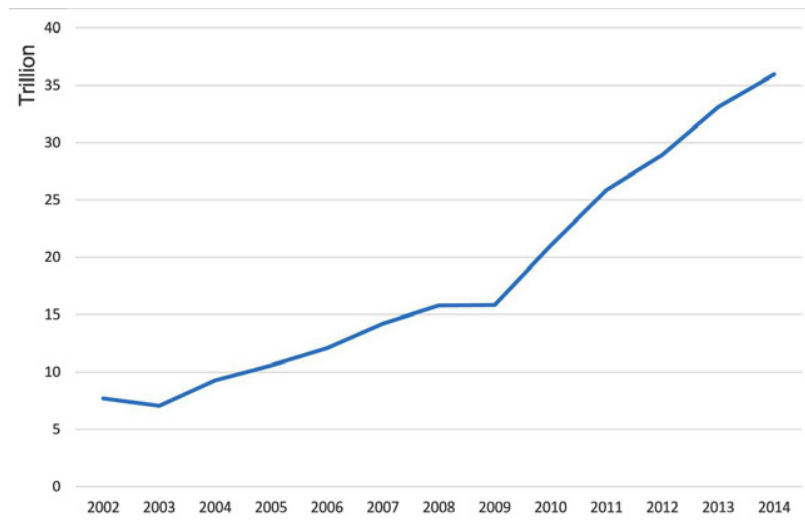

Figure 2. Yearly Hong Kong tourism expenditure, 2002-2014 
expenditure (totaling USD10.10 billion) and 51\% of overnight visitor expenditure (totaling USD24.81 billion). Many products in Hong Kong are highly competitive in terms of prices, quality assurance, variety, and services. The price level of many products is modestly lower in Hong Kong than in mainland China, mainly due to lower taxation in Hong Kong.

Central, Wan Chai, and Causeway Bay locate a wide range of famous, large-scale, must-visit shopping attractions (e.g., Time Square, Sogo, International Finance Centre, and Pacific Place) and also a vast number of retail stores that sell luxury brands, jewelry, cosmetics, perfumes, electronics, watches, etc. These areas are easily accessible by public transportation and have high shop density. They are the primary foci for tourist shoppers' activities and packed with tourists (especially those from mainland China) day and night. According to the Transport Department (2014), Wai Chai (covering Causeway Bay) and Central \& Western are among the three most popular shopping attractions for tourists. As such, Central, Wan Chai, and Causeway Bay are selected to represent the PTSA in this study. Comparatively, shopping attractions in the New Territories usually sell miscellaneous necessities for daily needs, which mainly serve local residents. Therefore, they are seldom visited by inbound tourist shoppers despite its large geographical area (Transport Department, 2014). Accordingly, the New Territories is selected to represent the UTSA in this study.

\subsection{Data}

Quarterly retail property price indices from 2002Q1 to 2014Q4 (observation period) of the PTSA and the UTSA are calculated using the repeat-sales method (detailed in Section 4.1). The data used for the index calculation are provided by a private database (Economic Property Research Center, EPRC) that records information on all property transactions from the Land Registry of Hong Kong since 1991. The property-level transaction information recorded in the EPRC database includes the property category (e.g., residential, office, commercial, and industrial), location (district, street, estate, building, floor, and flat), building completion date, transaction price, date, and type (e.g., agreement for sales and purchase and assignment). Various characteristics jointly ensure the high quality of the repeat-sales property index in Hong Kong, such as relatively homogeneous properties and the high proportion of repeat sales ${ }^{3}$ (Chau et al., 2005a). The quarterly tourist volume data and yearly tourism expenditure data are obtained from A Statistical Review of Hong Kong Tourism (various issues).

\footnotetext{
3 Though Chau et al. (2005a) only pointed it out in the housing market of Hong Kong, their statement largely applies to the retail property market of the city as well.
}

\section{Methodology}

\subsection{Repeat-sales property price indices}

The repeat-sales model is one of the two extensively used transaction-based property price index construction methods (Chau et al., 2018). The other one is the hedonic-pricing-based method (Rosen, 1974). The repeatsales model was first introduced by Bailey et al. (1963) and later enhanced by Case and Shiller $(1987,1989)$. As the name itself implies, the repeat-sales model strictly centers on properties that have been transacted at least twice within a specific time such that the price change of the same property can be compared over time. The model controls period-to-period differences in property attributes (i.e., constant quality) and calculates a housing price change indicator by confining the analysis to a small subset of all property transactions. Time-invariant explanatory variables are dropped out of the repeat-sales model.

The most general property price function can be written as:

$$
P_{i t}=c+\sum_{j} \beta_{j} X_{i j}+\sum_{t} \delta_{t} D_{i t}+\varepsilon_{i t},
$$

where: $P_{i t}$ is the price of property $i$ at time $t$ (in natural logarithm form); $X_{i j}$ is the $j$ th hedonic variable of property $i ; \beta_{j}$ is the coefficient of the $j$ th hedonic variable; $D_{i t}$ is the sales-time dummy variable ( 1 if property $i$ is sold at time $t$ and 0 otherwise); $\delta_{t}$ is the coefficient of $D_{i t} ; c$ is a constant; and $\varepsilon_{i t}$ is the error term.

As the repeat-sales model assumes constant property attributes, it can be treated as the difference of the transactions in consecutive time periods. The repeat-sales model can be mathematically expressed as:

$$
P_{i t}-P_{i s}=\delta_{t} D_{i t}-\delta_{s} D_{i s}+\varepsilon_{i t}-\varepsilon_{i s} .
$$

Repeat-sales price indices have been applied in a myriad of property markets. The most well-known one is the Standard and Poor's/Case-Shiller Home Price Indices for the United States. Other examples are 1) the Moody's/ REAL Commercial Property Price indices for the United States; 2) the Conventional Mortgage Home Price Index, which covers numerous U.S. cities and regions; 3 ) the Residex and RPData-Rismark indices for Australia; and 4) the Woningwaarde Index Kadaster for the Netherlands.

Despite its recognized usefulness, the repeat-sales model suffers from a few shortcomings (Chau et al., 2018), which are listed as follows: 1) In reality, property attributes and their shadow prices may not be time-constant as the repeat-sales model assumes. Instead, they may be time-varying. Some property attributes may change over time, such as views and accessibility. The most important attribute of the same property that will change over time is age. However, adjusting the age or depreciation effect in the repeat-sales model is not a trivial issue. An example is to use a non-linear age model (Chau et al., 2005b), which is computationally demanding. Fortunately, the depreciation of retail shops is insignificant in Hong Kong 
since the value of a shop attributable to the land is very high (more than $90 \%$ of the property value). Unlike the building structure, the land will not depreciate over time. Therefore, the depreciation of retail shops in Hong Kong is insignificant (Liu, 2014). Furthermore, shop owners are willing to spend resources to upkeep the properties because of their high value. The age adjustment issue is, therefore, not important when constructing a repeat-sales retail property price index in Hong Kong. However, possible changes in implicit prices over time because of changes in tastes or other factors cannot be easily resolved in the repeat-sales model and remain a standard assumption of a repeat-sales price index. 2) The repeat-sales index does not make use of all the available data. The repeat-sales model restricts its sample to properties that were transacted at least twice during the sampling period. Thus it ignores properties that were sold once and excludes a part of available transaction data. 3) There could be the sample selection bias. The repeat-sales model only uses properties transacted at least twice during the sampling period and leaves out those only transacted once. The repeatsales index is computed using a sample of more frequently traded properties than those excluded (only transacted once). Many studies have shown that properties that are more frequently transacted (also known as flippers) have different characteristics than those only transacted once. Therefore, the repeat-sales sample may be biased. As a result, repeat-sale properties are not a random sample of the population. Indeed, to reflect a full picture of the property market, all property transactions within the observation period should be taken into account. However, this requires information on all price-influencing attributes of transacted properties, which is often impossible or too expensive to obtain in reality. 4) The repeat-sales index is unstable and subject to revision when new transactions are added over time. As time passes and more property transaction data are added, the entire index has to be computed again, which often leads to changes in the index values computed previously. This is a common issue of transaction-based property price indices. However, it is an issue for index updating but not for analysis over a predefined observation period, such as this study.

To deal with the limitations of the repeat-sales model, researchers have developed a variety of methods. Case and Shiller (1987) showed that the estimation error enlarges with the holding period length and thus proposed a three-stage weighted repeat-sales method to down-weight properties with long holding periods. Goetzmann (1992) used a Bayesian repeat-sales modeling approach to improve price index estimation accuracy. Bourassa et al. (2013) presented the robust-regression-based repeat-sales method to down-weight problematic transactions on the basis of the magnitude of their residuals. Some studies have addressed the changes in characteristics problem of the repeat-sales model by adding controls, such as introducing hedonic variables. Case and Quigley (1991) were the first to do so: they proposed a hybrid technique that combines hedonic pricing and repeat-sales modeling to derive property price indices and developed a system of equations of single sales and repeat sales with either changed or unchanged attributes through a two-stage generalized least squares method. Many researchers, such as Quigley (1995), Englund et al. (1998), and Bourassa et al. (2006), have moved forward with the hybrid technique. Furthermore, some studies have aimed to relax the stringent requirement of the traditional repeat-sales model (exclusively focusing on the same property) and thus paired together sales of similar individual properties over time for the price index estimation. The earliest contribution can be traced back to McMillen (2012), who used pseudo-rather than factual or actual-repeat-sales data and proposed a propensity-score-based matching pair method. Guo et al. (2014) and Jiang et al. (2015b) proposed two other novel pseudo repeat-sales methods. All in all, the summary of the repeat-sales model development provided herein is far from exhaustive. Interested readers can refer to Chau et al. (2018) for a comprehensive review of the advancement of repeat-sales modeling approaches.

\subsection{Index frequency-conversion estimation procedure: the generalized inverse estimator}

Repeat retail property transactions are much scarcer than those of housing units, and the sample size used to construct the retail property price index is small. Therefore, the standard repeat-sales model described above cannot be adopted directly. Instead, we adopted a two-stage frequency-conversion estimation procedure, namely the Generalized Inverse Estimator proposed by Bokhari and Geltner (2012), which derives a high-frequency (quarterly in this study) price index from a staggered series of lowfrequency (yearly in this study) price indices.

The first stage of the Generalized Inverse Estimator is the construction of a staggered series of yearly price indices using the standard repeat-sales model. The second stage is finding a minimum norm least-squares solution (quarterly return) from a staggered series of yearly returns based on the Moore-Penrose pseudo-inverse matrix. The details of the Generalized Inverse Estimator can be found in Bokhari and Geltner (2012).

\subsection{Standard Granger causality tests}

To test the two hypotheses regarding the relationship between tourism development and retail property prices, we first adopted the Granger causality test (Granger, 1969) using data during the observation period (quarterly data from 2002Q1 to 2014Q4). The technique has extensively been used in various studies to identify the lead-lag relationship between two or more time-series data in multiple fields, such as economics (Roudi et al., 2019; T. P. Wu \& H. C. Wu, 2019), finance (Jiang et al., 2015a), management (Gupta \& Singh, 2016), transportation (Pacheco \& Fernandes, 2017), and tourism (Oh, 2005; Roudi et al., 2019). 
The standard Granger causality test is often based on a vector autoregressive model, which can be represented as follows:

$$
P_{t}=c+\sum_{i=1}^{n} \alpha_{i} P_{t-i}+\sum_{i=1}^{n} \beta_{i} T_{t-i}+u_{t},
$$

where: $P_{t}$ and $T_{t}$ are the retail property price (in real terms) and a tourism development measure (tourist volume or tourism expenditure) in natural logarithm form, respectively, at time $t ; \alpha_{i}$ and $\beta_{i}$ are the coefficients; $c$ is a constant; $n$ is the lag length; and $u_{t}$ is the error term. Equation (3) postulates that the retail property price is affected by its past values and the tourism development measure. We can conclude that the tourism development measure Granger causes retail property prices if some $\beta_{0 i}$ are significantly different from 0 .

The standard Granger causality test critically requires stationary time-series data (Engle \& Granger, 1987). In the case of non-stationary time-series data, first differences (changing from $P_{t}$ and $T_{t}$ to $\Delta P_{t}$ and $\Delta T_{t}$ ) are often taken to satisfy the stationary requirement.

\subsection{ECM-based Granger causality test}

In spite of its recognized usefulness, the standard Granger causality test, which is based on vector autoregressive models, is an overly simplistic technique and suffers from a number of limitations (Engle \& Granger, 1987). Applying vector autoregressive models to the first difference evidently eliminates valuable information about the cointegrated relationship amongst the data series. As such, in the case of non-stationary series that are known to be co-integrated, the ECM-based Granger causality test vastly outperforms the standard one and therefore has widely been used in previous studies (Arslanturk et al., 2011; Gupta \& Singh, 2016; Pacheco \& Fernandes, 2017; Muzindutsi \& Surujlal, 2018). The ECM is written as follows:

$$
P_{t}=c+\lambda \varepsilon_{t-1}+\sum_{i=1}^{n} \alpha_{i} P_{t-i}+\sum_{i=1}^{n} \beta_{i} T_{t-i}+u_{t}
$$

where: $\varepsilon_{t-1}$ is the error correction term (ECT) estimated from a long-run equilibrium model, reflecting the deviation from equilibrium in period $t-1$; and all other variables are as defined before. The ECM is essentially a vector autoregressive model except for the presence of the term $\lambda \varepsilon_{t-1}$. Granger causality can be inferred from the statistical significance of the ECT and the lagged variables.
The long-run equilibrium model can be expressed as follows:

$$
P_{t-1}=\kappa T_{t-1}+\gamma+\varepsilon_{t-1},
$$

where: $\kappa$ is a coefficient associated with $T_{t-1} ; \gamma$ is a constant; and all other variables are as defined before.

\section{Results}

\subsection{Descriptive statistics for the series used for Granger causality tests}

The quality of a repeat-sales price index relies on the transaction data used for estimation. Normally, various data filters, such as a bulk transaction filter and a pre-sales filter, are necessary to remove low-quality empirical data. Following Geltner and Pollakowski (2007), the filters used in this study are as follows: 1) pre-sales transaction filter, wherein property transactions that took place before the completion time of the property are removed; 2) bulk (or multi-assets, portfolio) transaction filter, wherein bulk transactions are excluded; 3 ) transaction instrument filter, wherein only data recorded in the Sale and Purchase Agreement of transacted properties are used; and 4) a potentially wrong data filter, wherein several potentially wrong repeat-sales observations are excluded, such as observations with a change in gross floor area and properties with different transaction prices on the same day.

Retail property price indices for the two areas are calculated using repeat-sales observations in Eviews (Version 10). The baseline index values in 2002Q1 of the two areas are set as 100 . As mentioned above, the retail property price index in the PTSA is computed using the Generalized Inverse Estimator with Matlab 2018. To remove the effect of inflation, retail property prices and tourism expenditure are deflated using the Hong Kong Consumer Price Index. Table 1 shows descriptive statistics for the series used for Granger causality analysis. Tourist volume and (real or deflated) tourism expenditure are, on average, 7.37 million and $\mathrm{HK} \$ 115.20$ trillion, respectively.

\subsection{Results of unit root tests}

Table 2 lists the results of unit root tests-more specifically, augmented Dickey-Fuller tests-for the two tourism development measures and the retail property price indices

Table 1. Descriptive statistics for the series used for Granger causality tests

\begin{tabular}{|l|l|c|c|c|c|}
\hline \multicolumn{2}{|c|}{ Variable } & Median & Std. Dev. & Maximum & Minimum \\
\hline \multirow{2}{*}{ Tourism development } & Tourist volume (unit: million) & 7.37 & 3.55 & 16.18 & 1.65 \\
\cline { 2 - 7 } & Tourism expenditure (unit: trillion HK\$) & 14.32 & 6.62 & 27.29 & 6.56 \\
\hline \multirow{2}{*}{ Retail property price } & PTSA & 182.22 & 197.74 & 807.15 & 93.30 \\
\cline { 2 - 7 } & UTSA & 180.91 & 153.78 & 636.46 & 100.68 \\
\hline
\end{tabular}


Table 2. Results of augmented Dickey-Fuller tests (unit root tests)

\begin{tabular}{|l|l|c|c|c|c|}
\hline \multicolumn{2}{|c|}{ Variable } & \multicolumn{2}{c|}{ Level } & \multicolumn{2}{c|}{ First-difference } \\
\cline { 3 - 6 } & $\begin{array}{c}\text { Without time } \\
\text { trend and } \\
\text { intercept }\end{array}$ & $\begin{array}{c}\text { With time } \\
\text { trend and } \\
\text { intercept }\end{array}$ & $\begin{array}{c}\text { Without time } \\
\text { trend and } \\
\text { intercept }\end{array}$ & $\begin{array}{c}\text { With time } \\
\text { trend and } \\
\text { intercept }\end{array}$ \\
\cline { 3 - 6 } & Tourist volume & 3.285 & -2.858 & $-4.665^{* * *}$ & $-7.748^{* * *}$ \\
\hline \multirow{2}{*}{ Tourism development } & Tourism expenditure & 2.563 & $-4.278^{* * *}$ & $-2.113^{* * *}$ & $-3.373^{*}$ \\
\hline Retail property price & PTSA & 1.591 & -3.066 & $-2.429^{* *}$ & $-3.988^{* *}$ \\
\cline { 2 - 6 } & UTSA & 2.647 & -2.107 & $-6.931^{* * *}$ & $-8.308^{* * *}$ \\
\hline
\end{tabular}

Note: ${ }^{* * *},{ }^{* *},{ }^{*}$ indicates that the null hypothesis that the series has a unit root (meaning the series is non-stationary) can be rejected at the 1,5 , and $10 \%$ level, respectively.

of the two areas (in natural logarithm form). ${ }^{4}$ The results show that both the retail property price indices and the tourist development series have a unit root and are nonstationary in level form, but they are first-difference stationary.

\subsection{Results of standard Granger causality tests}

As all of the series are $I(1)$, we use their first difference for standard Granger causality tests to determine whether tourism development is useful in forecasting retail property prices (or the lead-lag relationship between tourism development and retail property prices) in Eviews (Version 10). Table 3 displays the results of standard Granger causality tests (with up to 7 lags) for both the PTSA and the UTSA.
Table 3 shows that tourist volume Granger causes retail property prices of the PTSA when the lag length equals 4 , 5 , or 6 . In other words, the tourist volume contains information on future retail property prices. At other lags, no statistically discernible relationship between the two series can be observed. This outcome indicates that the Granger causality test highly depends on the lag length. Similarly, tourism expenditure Granger causes retail property prices of the PTSA at all lags (ranging from 1 to 7 ). The optimal lag length for the two causality tests is four based on the Akaike information criterion. All in all, the findings provide strong evidence supporting Hypothesis 1 .

Table 3 also shows the results of Granger causality tests for the UTSA. We find that there is no lead-lag relationship between tourism development (measured by

Table 3. Results of standard Granger causality tests for the two areas

\begin{tabular}{|c|c|c|c|c|c|c|c|c|c|c|c|c|c|c|}
\hline \multirow{2}{*}{ Direction of causality } & \multicolumn{2}{|c|}{1 lag } & \multicolumn{2}{|c|}{2 lags } & \multicolumn{2}{|c|}{3 lags } & \multicolumn{2}{|c|}{4 lags } & \multicolumn{2}{|c|}{5 lags } & \multicolumn{2}{|c|}{6 lags } & \multicolumn{2}{|c|}{7 lags } \\
\hline & F-stat. & Prob. & F-stat. & Prob. & F-stat. & Prob. & F-stat. & Prob. & $F$-stat. & Prob. & F-stat. & Prob. & F-stat. & Prob. \\
\hline \multicolumn{15}{|l|}{ PTSA } \\
\hline $\begin{array}{l}\text { Tourist volume } \rightarrow \text { Retail } \\
\text { property price }\end{array}$ & 2.027 & 0.161 & 0.976 & 0.385 & 1.310 & 0.284 & 3.174 & $0.024^{*}$ & 2.733 & $0.035^{*}$ & 2.437 & $0.047^{*}$ & 1.825 & 0.120 \\
\hline $\begin{array}{l}\text { Tourism expenditure } \rightarrow \\
\text { Retail property price }\end{array}$ & 4.906 & $0.032^{*}$ & 3.761 & $0.031^{*}$ & 3.655 & $0.020^{*}$ & 3.757 & $0.011^{\star}$ & 3.445 & $0.012^{*}$ & 3.462 & $0.010^{*}$ & 2.746 & $0.026^{*}$ \\
\hline \multicolumn{15}{|l|}{ UTSA } \\
\hline $\begin{array}{l}\text { Tourist volume } \rightarrow \text { Retail } \\
\text { property price }\end{array}$ & 0.976 & 0.328 & 0.665 & 0.520 & 0.336 & 0.800 & 0.368 & 0.830 & 0.870 & 0.511 & 0.775 & 0.596 & 0.351 & 0.923 \\
\hline $\begin{array}{l}\text { Tourism expenditure } \rightarrow \\
\text { Retail property price }\end{array}$ & 0.088 & 0.769 & 0.358 & 0.700 & 0.540 & 0.658 & 0.596 & 0.668 & 0.180 & 0.968 & 0.425 & 0.857 & 0.411 & 0.887 \\
\hline
\end{tabular}

Note: ${ }^{*}$ The null hypothesis that indicates no "causality" can be rejected at the $5 \%$ level; and all series are in first-difference.

\footnotetext{
4 Other unit root tests, such as the Kwiatkowski-PhillipsSchmidt-Shin test and the Phillips-Perron test, are also used. The results are highly similar to those of augmented DickeyFuller tests and thus are not presented here for brevity.
} 
either tourist volume or tourism expenditure) and retail property prices in the UTSA. This outcome is consistent with Hypothesis 2. Moreover, the result is highly robust across different lags and tourism development measures. As retail properties in the UTSA are mainly patronized by local residents rather than inbound tourists, it is reasonable that their prices are insensitive to tourism development. By and large, the outcomes confirm $\mathrm{Hy}$ pothesis 2 .

\subsection{Results of ECM-based Granger causality tests}

Johansen co-integration tests are conducted to test the co-integration relationship between tourism development and real retail property prices in the two areas. The results indicate that tourism development measures and retail property prices are co-integrated in the PTSA (trace stat. $=21.73$ or $16.08>95 \%$ critical value) but not in the UTSA (trace stat. $=10.04$ or $4.41<95 \%$ critical value), meaning that there is a long-run equilibrium relationship between tourism development and retail property prices in the PTSA (but not in the UTSA). As such, the ECM-based Granger causality test is only conducted for the PTSA.

Table 4 presents the results of the ECM-based Granger causality test for the PTSA and reflects the Granger causation from tourism development to retail property prices. The statistical significance of the ECTs and lagged variables suggests that we can reject the null hypothesis (tourism development does not Granger cause retail property prices) and provides evidence supporting the claim that retail property prices are Granger caused by tourism development in the PTSA. The ECT's coefficient, which measures the speed of market adjustments toward the long-run equilibrium, is negative and significant. The outcome indicates that when the retail property price temporarily deviates from its co-integrating relationship with tourism development, the retail property market quickly responds to restore the equilibrium. All in all, the findings from the ECMs further confirm Hypothesis 1.

Table 4. Results of ECM-based Granger causality tests for the PTSA

\begin{tabular}{|l|c|c|}
\hline \multicolumn{1}{|c|}{$\begin{array}{c}\text { Measure/ } \\
\text { conclusion }\end{array}$} & $\begin{array}{c}\text { ECM 1 } \\
\text { (independent } \\
\text { variable = tourist } \\
\text { volume) }\end{array}$ & $\begin{array}{c}\text { ECM 2 } \\
\text { (independent } \\
\text { variable = tourism } \\
\text { expenditure) }\end{array}$ \\
\hline $\begin{array}{l}\text { Coefficient of the } \\
\text { ECT }(t \text {-stat. for } \\
\text { the ECT) }\end{array}$ & $-0.289^{*}(2.39)$ & $-0.307^{*}(-2.11)$ \\
\hline $\begin{array}{l}F \text {-stat. for lagged } \\
\text { variables }\end{array}$ & $2.91^{*}$ & $3.98^{*}$ \\
\hline Adjusted R ${ }^{2}$ & 0.253 & 0.316 \\
\hline $\begin{array}{l}\text { Conclusion of } \\
\text { hypothesis test }\end{array}$ & Reject & Reject \\
\hline
\end{tabular}

Note: ${ }^{*}$ Significant at the $5 \%$ level.

\section{Discussion and conclusions}

Recently, tourism demand has dramatically increased everywhere (UNWTO, 2018). The connection between tourism development and economic growth has long been a focus of scholars worldwide. The linkages between tourism and property prices (not necessarily retail property prices) have been examined in several studies. Despite the importance of tourism development in shaping retail property prices in shopping destinations (e.g., Hong Kong), few studies have explored this topic comprehensively and investigated the differences in relationships between the two elements in different locales of a shopping destination.

Generally, tourism development pushes up the demand for retail properties that tourists frequently visit. This is particularly true in Hong Kong, a shopping destination widely known as a "shopping paradise". Hence, we propose a tourism-led growth in retail property prices hypothesis and suggest that the hypothesis holds in the PTSA but not in the UTSA. Based on the analysis of tourism development (measured by tourist volume and tourism expenditure) data and retail property indices in the PTSA and the UTSA from 2002Q1 and 2014Q4, our hypotheses are confirmed with the aid of standard and ECM-based Granger causality tests. Specifically, tourism development Granger causes retail property prices in the PTSA but not in the UTSA. That is, tourist volume and tourism expenditure can be used to better predict retail property prices in the PTSA than exclusively referring to the price history.

From an economic view, the ever-increasing tourist volume (or tourism expenditure) is a positive signal of the rise in retail property prices in the PTSA. In other words, tourism development can be a determinant of the overall growth in retail property prices in the PTSA in the long term. This study can be a valuable reference for the government, tourism policy-makers, practitioners, retailers, etc. Tourism policy-makers and practitioners can formulate targeted, appropriate, and effective policy measures or strategies, develop favorable destination images, and create a desirable environment to effectively satisfy the needs and preferences of tourist shoppers. For example, retailers can predict the development trend of tourism in the near future and take proactive measures to respond to the trend.

In addition to tourist-shopper-dominant and largescale boutique shops, chain stores, shopping centers, and commercial pedestrian streets, there are some small-scale and locally owned (or indigenous) stores and restaurants (e.g., working-class corner cafés and food shops) in the PTSA that mainly serve local residents (rather than tourists) and are only sporadically visited by tourists. In other words, in the PTSA, there are still unpopular tourist shopping destinations, which do not considerably benefit from the inflow of tourists but have to pay increasing property rentals (or prices). The tourism-induced price increment brings economic pressure to such shops and stores and harms their normal functioning. Thus, commercial gen- 
trification progressively occurs (Gant, 2015; Cocola-Gant, 2018). As a result, some long-established shops and stores possibly cannot afford high rentals (or prices) and may be displaced. To ease citizens' daily lives and keep the city diverse and competitive, paying great heed to the adverse effects of tourism development on local-dominant shops and stores in the PTSA is indispensable. As such, the city's government can craft policy measures (e.g., tax reductions or exemptions, financial subsidies, and transfer payments) for these important local-dominant shops and stores. These policy measures should be reviewed and amended periodically to ensure their appropriateness. However, such policy measures are theoretically simple but practically challenging.

Considering that the New Territories does not significantly appeal to tourist shoppers and that the retail property volume in Hong Kong seems adequate, establishing ex nihilo strategies (typically in a product differentiation form) for the UTSA is suggested (Li et al., 2019). Clearly distinguishing the New Territories from other touristshopper-dominant areas and making this kind of area attractive to non-shopping-targeted tourists might better cater to tourists' needs and preferences. Accordingly, the government can formulate appropriate plans for these areas to avoid malign competition with PTSA, and retailers and property developers can make smart decisions to reduce investment risks.

Several research limitations exist in this paper. First, as in many existing studies, tourist volume and tourism expenditure are used as proxies for tourism development in this study. However, we should not merely equate tourism development with increases in tourist volume and tourism expenditure. The use of other indicators or an integrated (or combined) tourism index might be worth exploring in future research. Second, this study adopts a bivariate analysis for investigating locale-specific relationships between tourism and retail property prices. Indeed, conducting a multivariate analysis is more rigorous than what we do in this study. However, including more locale-specific variables is difficult, if not impossible, due to data unavailability. Third, we select two areas: one is Central, Wan Chai, and Causeway Bay, referring to the PTSA. The other is the New Territories, referring to the UTSA. However, these two areas have many differences, not only in the number of tourist activities. Perhaps, it is better to choose the PTSA far away from the economic center, and the areas around Disneyland may be a right choice. Notwithstanding, retail property transaction data are highly scarce in these areas. This feature prevents us from constructing repeat-sales (even pseudo repeat-sales) price indices.

\section{Acknowledgements}

This research was supported by grants from the grants from the National Natural Science Foundation (Project No. 51778530). The authors are grateful to the three re- viewers for their constructive comments.

\section{References}

Arslanturk, Y., Balcilar, M., \& Ozdemir, Z. A. (2011). Time-varying linkages between tourism receipts and economic growth in a small open economy. Economic Modelling, 28(1-2), 664-671. https://doi.org/10.1016/j.econmod.2010.06.003

Bailey, M. J., Muth, R. F., \& Nourse, H. O. (1963). A regression method for real estate price index construction. Journal of the American Statistical Association, 58(304), 933-942. https://doi.org/10.1080/01621459.1963.10480679

Biagi, B., Brandano, M. G., \& Lambiri, D. (2015). Does tourism affect house prices? Evidence from Italy. Growth and Change, 46(3), 501-528. https://doi.org/10.1111/grow.12094

Biagi, B., Brandano, M. G., \& Caudill, S. B. (2016). Tourism and house prices in Italy: a latent class approach. Tourism Economics, 22(5), 964-978. https://doi.org/10.5367/te.2015.0470

Biagi, B., \& Faggian, A. (2004). The effect of tourism on the house market: the case of Sardinia. Paper presented at the 44th Congress of the European Regional Science Association: "Regions and Fiscal Federalism".

Biagi, B., Lambiri, D., \& Faggian, A. (2012). The effect of tourism on the housing market. In M. Uysal, R. Perdue, \& M. J. Sirgy (Eds.), Handbook of tourism and quality-of-life research: enhancing the lives of tourists and residents of host communities (pp. 635-652). Springer Science \& Business Media. https://doi.org/10.1007/978-94-007-2288-0_36

Bokhari, S., \& Geltner, D. (2012). Estimating real estate price movements for high frequency tradable indexes in a scarce data environment. The Journal of Real Estate Finance and Economics, 45(2), 522-543. https://doi.org/10.1007/s11146-010-9261-4

Bourassa, S. C., Hoesli, M., \& Sun, J. (2006). A simple alternative house price index method. Journal of Housing Economics, 15(1), 80-97. https://doi.org/10.1016/j.jhe.2006.03.001

Bourassa, S. C., Cantoni, E., \& Hoesli, M. (2013). Robust repeat sales indexes. Real Estate Economics, 41(3), 517-541. https://doi.org/10.1111/reec.12013

Case, B., \& Quigley, J. M. (1991). The dynamics of real estate prices. The Review of Economics and Statistics, 73(1), 50-58. https://doi.org/10.2307/2109686

Case, K. E., \& Shiller, R. J. (1987). Prices of single family homes since 1970: new indexes for four cities (Working paper No. 2393). National Bureau of Economic Research, Cambridge, Mass., USA. https://doi.org/10.3386/w2393

Case, K. E., \& Shiller, R. J. (1989). The efficiency of the market for single-family homes. The American Economic Review, 79(1), 125-137.

Chau, K. W., Wong, S. K., Liang, J., McCluskey, W., \& Cunningham, C. (2018). Transaction-based indices. In B. D. MacGregor, R. Schulz, \& R. K. Green (Eds.), Routledge companion to real estate investment. Routledge. https://doi.org/10.1201/9781315775579-10

Chau, K. W., Leung, A. Y. T., Yiu, C. Y., \& Wong, S. K. (2003). Estimating the value enhancement effects of refurbishment. Facilities, 21(1/2), 13-19. https://doi.org/10.1108/02632770310460504

Chau, K. W., Wong, S. K., \& Yiu, C. Y. (2004). The value of the provision of a balcony in apartments in Hong Kong. Property Management, 22(3), 250-264.

https://doi.org/10.1108/02637470410545020 
Chau, K. W., Wong, S. K., Yiu, C. Y., \& Leung, H. F. (2005a). Real estate price indices in Hong Kong. Journal of Real Estate Literature, 13(3), 337-356.

Chau, K. W., Wong, S. K., \& Yiu, C. Y. (2005b). Adjusting for non-linear age effects in the repeat sales index. The Journal of Real Estate Finance and Economics, 31(2), 137-153. https://doi.org/10.1007/s11146-005-1369-6

Chen, C. F., \& Rothschild, R. (2010). An application of hedonic pricing analysis to the case of hotel rooms in Taipei. Tourism Economics, 16(3), 685-694. https://doi.org/10.5367/000000010792278310

Choi, M., Law, R., \& Heo, C. Y. (2016). Shopping destinations and trust-tourist attitudes: scale development and validation. Tourism Management, 54, 490-501. https://doi.org/10.1016/j.tourman.2016.01.005

Cocola-Gant, A. (2018). Tourism gentrification. In L. Lees, \& M. Phillips (Eds.), Handbook of gentrification studies. Edward Elgar Publishing. https://doi.org/10.4337/9781785361746.00028

Engle, R. F., \& Granger, C. W. (1987). Co-integration and error correction: representation, estimation, and testing. Econometrica: Journal of the Econometric Society, 55(2), 251-276. https://doi.org/10.2307/1913236

Englund, P., Quigley, J. M., \& Redfearn, C. L. (1998). Improved price indexes for real estate: measuring the course of Swedish housing prices. Journal of Urban Economics, 44(2), 171-196. https://doi.org/10.1006/juec.1997.2062

Espinet, J. M., Saez, M., Coenders, G., \& Fluvià, M. (2003). Effect on prices of the attributes of holiday hotels: a hedonic prices approach. Tourism Economics, 9(2), 165-177. https://doi.org/10.5367/000000003101298330

Fereidouni, H. G. (2013). Determinants of foreign investments in residential properties: evidence from Malaysian states. International Journal of Strategic Property Management, 17(3), 317-322. https://doi.org/10.3846/1648715X.2013.822436

Gant, A. C. (2015). Tourism and commercial gentrification. In Proceedings of the RC21 International Conference on "The Ideal City: Between Myth and Reality, Representations, Policies, Contradictions and Challenges for Tomorrow's Urban Life", Urbino, Italy (pp. 27-29).

Geltner, D., \& Pollakowski, H. (2007). A set of indexes for trading commercial real estate based on the real capital analytics transaction prices database. MIT Center for Real Estate.

Goetzmann, W. N. (1992). The accuracy of real estate indices: repeat sale estimators. The Journal of Real Estate Finance and Economics, 5(1), 5-53. https://doi.org/10.1007/BF00153997

Granger, C. W. J. (1969). Investigating causal relations by econometric models and cross-spectral methods. Econometrica: Journal of the Econometric Society, 37(3), 424-438. https://doi.org/10.2307/1912791

Gu, X., Li, G., Chang, X., \& Guo, H. (2017). Casino tourism, economic inequality, and housing bubbles. Tourism Management, 62, 253-263. https://doi.org/10.1016/j.tourman.2017.04.006

Guo, X., Zheng, S., Geltner, D., \& Liu, H. (2014). A new approach for constructing home price indices: the pseudo repeat sales model and its application in China. Journal of Housing Economics, 25, 20-38. https://doi.org/10.1016/j.jhe.2014.01.005

Gupta, P., \& Singh, A. (2016). Causal nexus between foreign direct investment and economic growth: a study of BRICS nations using VECM and Granger causality test. Journal of Advances in Management Research, 13(2), 179-202. https://doi.org/10.1108/JAMR-04-2015-0028

Hong Kong Tourism Board (various issues). (n.d.). A statistical review of Hong Kong tourism.
Hui, E. C. M., Zhong, J. W., \& Yu, K. H. (2012). The impact of landscape views and storey levels on property prices. Landscape and Urban Planning, 105(1-2), 86-93.

https://doi.org/10.1016/j.landurbplan.2011.12.002

Jiang, B., Liang, S., \& Yuan, W. (2015a). Observational evidence for impacts of vegetation change on local surface climate over northern China using the Granger causality test. Journal of Geophysical Research: Biogeosciences, 120(1), 1-12. https://doi.org/10.1002/2014JG002741

Jiang, L., Phillips, P. C., \& Yu, J. (2015b). New methodology for constructing real estate price indices applied to the Singapore residential market. Journal of Banking \& Finance, 61, S121S131. https://doi.org/10.1016/j.jbankfin.2015.08.026

Kattiyapornpong, U., \& Miller, K. E. (2012). Propensity to shop: identifying who shops til they drop. Journal of Travel \& Tourism Marketing, 29(6), 552-565. https://doi.org/10.1080/10548408.2012.703027

Kavetsos, G. (2012). The impact of the London Olympics announcement on property prices. Urban Studies, 49(7), 1453-1470. https://doi.org/10.1177/0042098011415436

Kemperman, A. D., Borgers, A. W., \& Timmermans, H. J. (2009). Tourist shopping behavior in a historic downtown area. Tourism Management, 30(2), 208-218.

https://doi.org/10.1016/j.tourman.2008.06.002

Kim, H. J., \& Chen, M. H. (2006). Tourism expansion and economic development: the case of Taiwan. Tourism Management, 27(5), 925-933. https://doi.org/10.1016/j.tourman.2005.05.011

Kontokosta, C. (2012). The price of victory: the impact of the Olympic Games on residential real estate markets. Urban Studies, 49(5), 961-978. https://doi.org/10.1177/0042098011411952

Law, R., \& Au, N. (2000). Relationship modeling in tourism shopping: a decision rules induction approach. Tourism Management, 21(3), 241-249. https://doi.org/10.1016/S0261-5177(99)00056-4

Lee, S. K., \& Jang, S. (2012). Premium or discount in hotel room rates? The dual effects of a central downtown location. Cornell Hospitality Quarterly, 53(2), 165-173. https://doi.org/10.1177/1938965512441056

Li, Y., Yang, L., Shen, H., \& Wu, Z. (2019). Modeling intra-destination travel behavior of tourists through spatio-temporal analysis. Journal of Destination Marketing \& Management, 11, 260-269. https://doi.org/10.1016/j.jdmm.2018.05.002

Liu, Y. (2014). The impact of tourist shoppers on the pricing of street level retail shops. HKU Theses Online (HKUTO).

Liu, Y., Yang, L., \& Chau, K. W. (2020). Impacts of tourism demand on retail property prices in a shopping destination. Sustainability, 12(4), 1361. https://doi.org/10.3390/su12041361

Lu, Q., \& Yang, Y. (2015). A longitudinal study of the impact of the Sydney Olympics on real estate markets. International Journal of Event and Festival Management, 6(1), 4-17. https://doi.org/10.1108/IJEFM-02-2014-0007

McMillen, D. P. (2012). Repeat sales as a matching estimator. Real Estate Economics, 40(4), 745-773. https://doi.org/10.1111/j.1540-6229.2012.00343.x

Meng, F., \& Xu, Y. (2012). Tourism shopping behavior: planned, impulsive, or experiential? International Journal of Culture, Tourism and Hospitality Research, 6(3), 250-265. https://doi.org/10.1108/17506181211246401

Moscardo, G. (2004). Shopping as a destination attraction: an empirical examination of the role of shopping in tourists' destination choice and experience. Journal of Vacation Marketing, 10(4), 294-307. https://doi.org/10.1177/135676670401000402 
Murphy, L., Moscardo, G., Benckendorff, P., \& Pearce, P. (2011). Evaluating tourist satisfaction with the retail experience in a typical tourist shopping village. Journal of Retailing and Consumer Services, 18(4), 302-310.

https://doi.org/10.1016/j.jretconser.2011.02.004

Muzindutsi, P. F., \& Surujlal, J. (2018). Housing property market and tourism accommodation in South Africa: time series analysis. International Journal of Economic Policy in Emerging Economies, 11(3), 270-281. https://doi.org/10.1504/IJEPEE.2018.093953

Nicholls, S., \& Crompton, J. L. (2007). The impact of a golf course on residential property values. Journal of Sport Management, 21(4), 555-570. https://doi.org/10.1123/jsm.21.4.555

Oh, C. O. (2005). The contribution of tourism development to economic growth in the Korean economy. Tourism Management, 26(1), 39-44.

https://doi.org/10.1016/j.tourman.2003.09.014

Pacheco, R. R., \& Fernandes, E. (2017). International air passenger traffic, trade openness and exchange rate in Brazil: a Granger causality test. Transportation Research Part A: Policy and Practice, 101, 22-29.

https://doi.org/10.1016/j.tra.2017.04.026

Pantano, E., \& Dennis, C. (2019). Store buildings as tourist attractions: mining retail meaning of store building pictures through a machine learning approach. Journal of Retailing and Consumer Services, 51, 304-310.

https://doi.org/10.1016/j.jretconser.2019.06.018

Roudi, S., Arasli, H., \& Akadiri, S. S. (2019). New insights into an old issue-examining the influence of tourism on economic growth: evidence from selected small island developing states. Current Issues in Tourism, 22(11), 1280-1300. https://doi.org/10.1080/13683500.2018.1431207

Quigley, J. M. (1995). A simple hybrid model for estimating real estate price indexes. Journal of Housing Economics, 4(1), 1-12. https://doi.org/10.1006/jhec.1995.1001

Rosen, S. (1974). Hedonic prices and implicit markets: product differentiation in pure competition. Journal of Political Economy, 82(1), 34-55. https://doi.org/10.1086/260169

Schäfer, P., \& Hirsch, J. (2017). Do urban tourism hotspots affect Berlin housing rents? International Journal of Housing Markets and Analysis, 10(2), 231-255.

https://doi.org/10.1108/IJHMA-05-2016-0031

Schamel, G. (2012). Weekend vs. midweek stays: modelling hotel room rates in a small market. International Journal of Hospitality Management, 31(4), 1113-1118.

https://doi.org/10.1016/j.ijhm.2012.01.008
Song, H., Li, G., Witt, S. F., \& Fei, B. (2010). Tourism demand modelling and forecasting: how should demand be measured? Tourism Economics, 16(1), 63-81. https://doi.org/10.5367/000000010790872213

Transport Department. (2014). Travel Characteristics Survey 2011 Final Report. Hong Kong SAR Government, Hong Kong.

Turner, L. W., \& Reisinger, Y. (2001). Shopping satisfaction for domestic tourists. Journal of Retailing and Consumer Services, 8(1), 15- 27. https://doi.org/10.1016/S0969-6989(00)00005-9

UNWTO. (2018). UNWTO tourism highlights: 2018 edition. https://www.e-unwto.org/doi/pdf/10.18111/9789284419876

Wang, D., \& Nicolau, J. L. (2017). Price determinants of sharing economy based accommodation rental: a study of listings from 33 cities on Airbnb.com. International Journal of Hospitality Management, 62, 120-131.

https://doi.org/10.1016/j.ijhm.2016.12.007

White, P. J., \& Mulligan, G. F. (2002). Hedonic estimates of lodging rates in the four corners region. The Professional Geographer, 54(4), 533-543. https://doi.org/10.1111/0033-0124.00348

Wu, T. P., \& Wu, H. C. (2019). The link between tourism activities and economic growth: evidence from China's provinces. Tourism and Hospitality Research, 19(1), 3-14. https://doi.org/10.1177/1467358416683769

Yang, L., Zhou, J., Shyr, O. F., \& Huo, D. (2019a). Does bus accessibility affect property prices? Cities, $84,56-65$. https://doi.org/10.1016/j.cities.2018.07.005

Yang, L., Chau, K. W., \& Wang, X. (2019b). Are low-end housing purchasers more willing to pay for access to public services? Evidence from China. Research in Transportation Economics, 76, 100734. https://doi.org/10.1016/j.retrec.2019.06.001

Yang, L., Chau, K. W., Szeto, W. Y., Cui, X., \& Wang, X. (2020a). Accessibility to transit, by transit, and property prices: spatially varying relationships. Transportation Research Part D: Transport and Environment, 85, 102387. https://doi.org/10.1016/j.trd.2020.102387

Yang, L., Chu, X., Gou, Z., Yang, H., Lu, Y., \& Huang, W. (2020b). Accessibility and proximity effects of bus rapid transit on housing prices: heterogeneity across price quantiles and space. Journal of Transport Geography, 88, 102850. https://doi.org/10.1016/j.jtrangeo.2020.102850

Zaidan, E. A. (2016). Tourism shopping and new urban entertainment: a case study of Dubai. Journal of Vacation Marketing, 22(1), 29-41. https://doi.org/10.1177/1356766715589426

Zhang, H., Zhang, J., Lu, S., Cheng, S., \& Zhang, J. (2011). Modeling hotel room price with geographically weighted regression. International Journal of Hospitality Management, 30(4), 1036-1043. https://doi.org/10.1016/j.ijhm.2011.03.010 